\title{
Pre-aeration and Transversal Baffling Effect on Aerated Grit Chamber Performance of Kufa Wastewater Treatment Plant
}

\author{
Dr. Hasan Mahdi Mohammed Al-Khateeb ${ }^{1}$ \\ ${ }^{1}$ Civil Eng. Dep., Faculty of Engineering, University of Kufa, Kufa 21, Kufa District, Najaf Province, Iraq
}

\begin{abstract}
This paper investigates solutions for a problem of heavy loads of grits and grease encountered in a 50,000 m3/day capacity municipal wastewater treatment plant of Kufa city located at $160 \mathrm{Km}$ south of Baghdad in Iraq. Total suspended solids TSS concentrations in the influent were $410-780$ ppm causing about $1-2$ ton/day of grits to deposit in a reducing flow velocity basin located in between the fine screen and the aerated grit removal chamber. Oil and grease $O \& G$ were found with high concentrations 145 - 255 ppm in the raw sewage causing operational problems in secondary treatment. The solutions investigated were; using pre-aeration in the reducing flow velocity basin, installing effluent transversal baffle at the last $35.5 \mathrm{~cm}$ length section before end wall of the aerated grit chamber of $14.8 \mathrm{~m}$ total length, and longitudinal diffused aeration condition near baffle location. Six operational cases were investigated with various installations of baffle submerged depth, pre-aeration and longitudinal chamber aeration conditions. For each of the six cases studied, three daily samples for each of influent, effluent and settled grits were collected and tested. Sampling was carried out for seven days period for each of the six cases at 9:00am, 12:00pm and 2:00 pm in order to cover quality possible variation. Influent and effluent samples were tested for TSS, and O\&G, while grit samples were tested for total organic carbon TOC. Flow rate of the chamber was observed three times daily at the mean time of sampling by means of a Parshal Flume installed downstream the chamber. Longitudinal and transversal local flow velocity measurements were carried out by means of a flow velocity meter specially developed and calibrated for the field work. Three transversal sections were adopted along the chamber. First section was at 3.24m behind the inlet wall, second section was at $8.24 \mathrm{~m}$ from inlet wall, corresponding to the center of the middle air diffuser, while third one was at $13.24 \mathrm{~m}$ from inlet wall. Each of the three transversal sections was subdivided into five successive bays of $0.5 \mathrm{~m}$ width each for the main channel of the chamber. At centerline of every bay, point (local) flow velocity was measured at water depths $0.25,0.75,1.25,1.75$, 2.25, 2.75 and $3.25 \mathrm{~m}$ for both longitudinal (main) and transversal directions. Both longitudinal and transversal local velocities measured were divided by the main average flow velocity to get dimensionless relative flow velocity distribution along the chamber in both directions. The results showed that pre-aeration of $7.5 \mathrm{~m}^{3}$ air/ $\mathrm{hr} . \mathrm{m}^{3}$ water increased TSS and O\&G removal efficiencies of the grit chamber with $43 \%$ and $134 \%$, respectively. Installing the transversal baffle with a depth corresponds to $50 \%$ of water entire depth beside the same pre-aeration have together greater effect to increase O\&G removal efficiency with 209\%. However, the best dual removal efficiency for both TSS and O\&G was through installing the transversal baffle with submerged depth of $24 \%$ of entire water depth and the same pre-aeration. Such conditions increased TSS removal efficiency by $44.5 \%$ and increased O\&G removal efficiency by $170 \%$, and neither adversely effected the helical flow velocity distribution pattern nor the longitudinal flow. TOC results indicated relatively long detention time adopted in the chamber causing considerable deposition of organic matters with the grits removed.
\end{abstract}

Keywords: Aerated, Grit, Chamber, Pre-aeration, Baffling, Performance.

\section{Introduction}

Preliminary removal of wastewater constituents such as sticks, rags, floatables, grits, and grease has become necessary stage with developing mechanization of treatment plants. Such constituents may cause maintenance or operational problems with the treatment operations, processes, and ancillary systems. Preliminary stage is typically begin with screens followed by grit removal chambers [1]. Commonly used grit chambers are: velocity controlled grit chambers, aerated grit chambers, and vortextype grit chambers. Major function of grit chambers is to remove grits from raw wastewater such as dust, sand, cinder, coffee grounds, bone chips, seeds, eggshells, and other materials that are nonputrescible and heavier than organic matter [2]. However, minor functions are usually achieved in aerated grit chambers, that are: removal of oil and grease when skimming is provided [3] and driving some Oxygen into the sewage [4]. The problem on which this research focusing is treatment of heavy loads of grits and grease that sometimes contained in raw municipal wastewater causing effective grit deposition a head of grit chamber and considerable oil and grease loads to secondary (biological) treatment. High fluctuation in concentrations of grits in raw municipal wastewater may happened in wastewater collected by combined sewerage networks [5], [6], but fluctuation of oil and grease concentration may refer to industrial effluents contribution in the raw wastewater [6], [7].

\section{Problem of Study}

Heavy load problem of grits and grease is encountered in the municipal wastewater treatment plant in Kufa located at 160 $\mathrm{Km}$ south of Baghdad in Iraq. The plant was constructed during 2011 - 2014 with a capacity of $50,000 \mathrm{~m}^{3} /$ day adopting bioshaft (biofilm) technology. Since 2009, six neighborhoods with about $65 \mathrm{Km}$ total length sanitary sewage network has been completely constructed to serve about 80,000 population in Kufa district. That network was designed to discharge the sewage collected to the treatment plant. As the plant started operation at the beginnings of 2015, the network was discharging during 2009 - 2015, partially, to an old treatment plant south of kufa with an average capacity of $27,000 \mathrm{~m}^{3} /$ day which, in turn, was 


\section{International Journal of Science and Research (IJSR) \\ ISSN (Online): 2319-7064}

Index Copernicus Value (2013): 6.14 | Impact Factor (2014): 5.611

mainly serving kufa city center. However, the old plant was overloaded. Thus, it served the six neighborhoods at night (when minimum discharge rate comes from city center), while it served the center during the day. This critical operation status has lead to very slow flow velocities of the sewage in the net during the day causing considerable deposition of heavy sludges. On the other hand, separate system sewerage network of 9 neighborhoods were under construction during 2013 - 2015 in Najaf city 10 Km east of the plant. Although the network of those neighborhoods designed to discharge the sewage to a wastewater treatment plant located on the south waste of Najaf City but, that plant is still under construction right now (expected date of operation is end of 2016). Therefore, the sewage of the 9 neighborhoods was discharged to the $50,000 \mathrm{~m}^{3} /$ day new plant of Kufa. In addition, water produced from dewatering excavations while constructing the network of the 9 neighborhoods was discharged eventually to the Kufa new plant, too. With starting operation of the new Kufa plant at February 2015, severe problem of heavy grit loads in the raw sewage was observed. That grit load came from the deposited sludges in the network of the 6 neighborhoods of Kufa, and also from the water discharged from dewatering activities of the 9 neighborhoods of Najaf City. This problem appeared as unexpected deposition of grits just behind the screens and ahead of the grit removal chambers. The grit removal facility of the plant consists of two identical and parallel aerated grit removal chambers, Figure1 and Figure2. About $1-2$ ton/day of grits were depositing in a reducing flow velocity basin located in between the fine screen and the grit removal chamber, Photo 1 . The basin has $4.2 \mathrm{~m} \mathrm{X}$ $4.2 \mathrm{~m}$ plane dimensions with flat bottom. Its desired function was to receive the wastewater flow from the screen downstream channel and reduce its velocity, permitting an optional addition of Enzymes that help in oil degradation before entering the grit chamber. Oil and grease were found with high concentrations (145 - $255 \mathrm{ppm})$ in the raw sewage causing operational problems in secondary treatment. This oil and grease is thought to come from an industrial area located between Najaf City and Kufa City.

\section{Objective}

The objective of this study is to investigate the effect of preaeration, effluent transversal baffle installation, and longitudinal diffused aeration condition near baffle location on aerated grit chamber performance for both grits and grease removal. The author (as he was the consultant engineer supervising plant initial operation) suggested the pre-aeration and the transversal baffle installation as solution tools to overcome the problem of grit deposition in the bottom of the reducing flow velocity basin, and to enhance oil and grease removal. The pre-aeration was made by means of vertical pipes equipped with horizontal nozzles mounted on wall at $0.4 \mathrm{~m}$ height above the flat bottom of the $4.2 \mathrm{~m} \mathrm{X}$ $4.2 \mathrm{~m}$ reducing flow velocity basin with a spacing of $1-1.1 \mathrm{~m}$, Photo 2. The transversal baffle was situated on $0.335 \mathrm{~m}$ ahead of the end wall of the grit removal chambers, to retain floating oil and grease layer not to escape with the effluent Photo 3 . The distance $0.335 \mathrm{~m}$ cannot be increased because of scraper structure movement limitation.

\section{Background and Literature Review}

Aerated grit chambers exhibit consistent removal efficiency over a wide flow range. They simulate, to a certain extent, the spiral flow aeration tanks used in wastewater treatment [1]. Conceptually, the influent to the chamber is slowed down to well under $0.1 \mathrm{~m} / \mathrm{s}$ for peak flow. Then, a spiral shaped flow pattern is generated in the chamber using air diffusers jetting air, usually, along one side of the chamber on about 2 feet above chamber bottom. Such flow pattern is usually called Helical flow, Figure 3 . The spiral velocity (or so called roll velocity) can be adjusted according to specific gravity and size of the grit to be removed. The roll velocity is almost ranged between $0.6-0.8 \mathrm{~m} / \mathrm{s}$ at surface [2]. By means of this way, $100 \%$ grit removal may be achieved and the grit is well washed [9]. Generally, grits of $0.2 \mathrm{~mm}$ diameters or larger with approximately 2.65 specific gravities are designed to be removed by aerated grit chambers. Appropriate detention times for these particles for removal are ranged between 2 and 5 minutes [1], [10]. However, when smaller particles is desired to be removed, or if the chamber is also for pre-aeration, longer detention times may be required. Efficiency of particles removal in an aerated grit chambers is affected by hydraulic control to minimize short-circuiting[11]. The Short-circuiting can be avoided through adopting suitable tank geometry, and by the relative locations and orientations of the chamber inlet and outlet structures[12]. The placement of longitudinal or transverse baffles with respect to flow may also be a factor in preventing short circuiting [13], [14]. Type of equipment used in withdrawing out settled grits effects the quality of grit removed. The most commonly used equipments are the screw conveyor, chain and bucket, air lift pump, tubular conveyor, water jet pump, and grit pump [12],[15]. Through this study, performance of aerated grit chamber is investigated as affected by flow rates and distribution of air and transversal baffling.

\section{Experimental Work}

\subsection{Description of Chambers}

The aerated grit removal unit of the plant consists of two attached, parallel and identical grit chambers with $14.8 \mathrm{~m}$ long and $3.9 \mathrm{~m}$ working depth (total depth is $4.72 \mathrm{~m}$ ), Figure 1 and Figure 2. Each chamber has an interior width of $4.2 \mathrm{~m}$ at top and $2.1 \mathrm{~m}$ at bottom, with longitudinal concrete baffle (14.8m long $x 2.62 \mathrm{~m}$ height $\times 0.2 \mathrm{~m}$ thick) of which $1.7 \mathrm{~m}$ height is desired to work as submerged. Each chamber has a $1.5 \mathrm{~m}$ width skimmer and $1.7 \mathrm{~m}$ width scraper. The skimmer moves along the chamber within grease skimming side channel leaving a $2.5 \mathrm{~m}$ net width for the helical main flow. The scraper moves together with the skimmer but at the bottom of the chamber. They are mounted and mobilized by means of a longitudinal moving bridge. The scraper drafts settled grits to a bottom pit located at the flow entrance side of the chamber with a depth of $1.5 \mathrm{~m}$ to be temporarily stored. Air lift pump, intermittently, discharges the settled grits into sand and grit classifier. 


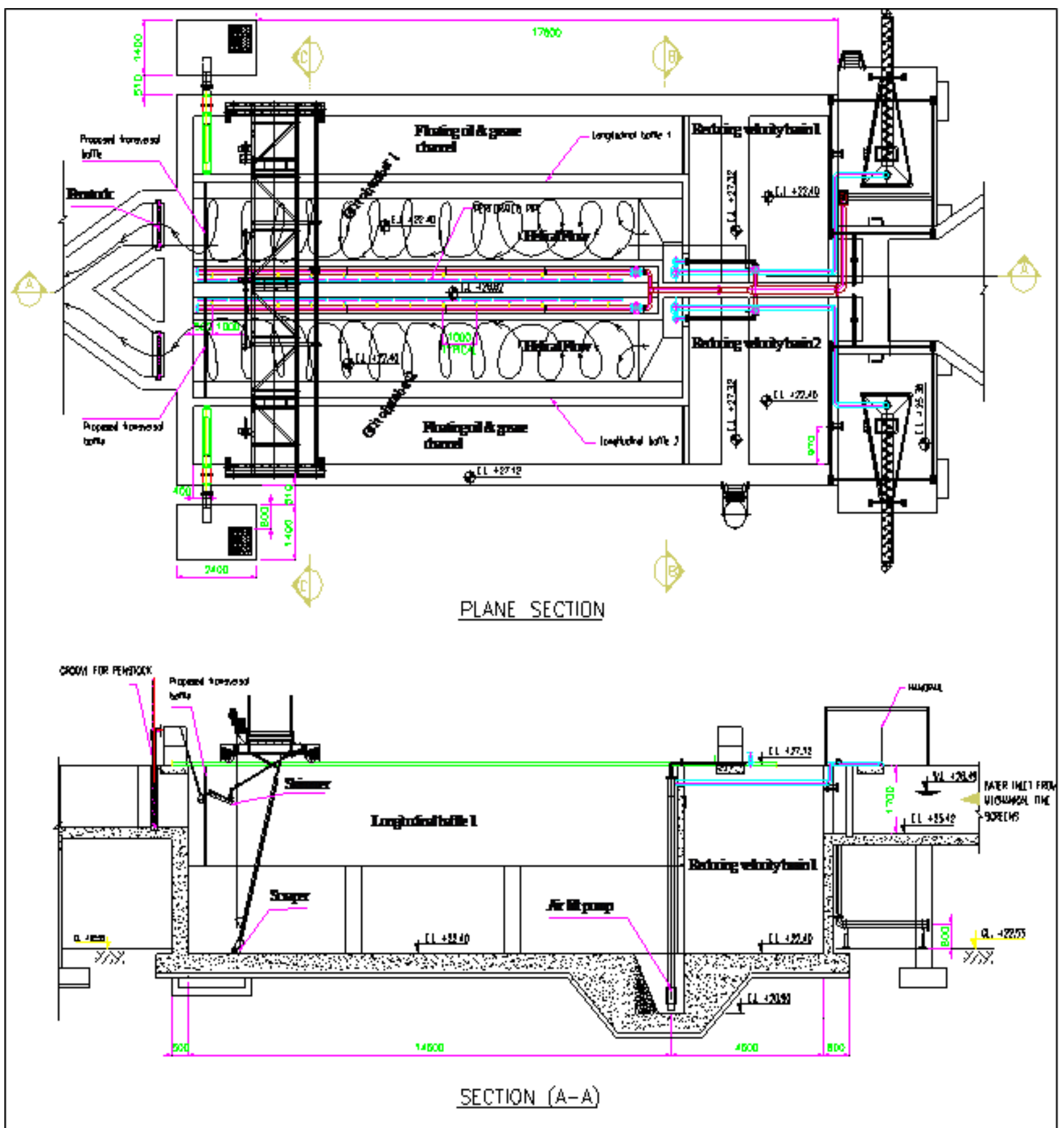

Figure 1: Sketch of grit chamber adopted in 50,000 m3/day capacity new municipal wastewater treatment plant of Kufa, [8].

Three identical blowers supply atmospheric air to the two chambers through galvanized pipe network. The network has check and gate valves, pressure gauges and pieces of $0.9 \mathrm{~m}$ long horizontal multiport diffusers (perforated pipes) through which air is controlled to enter the chambers and cause the helical flow. Each chamber has 13 diffuser pipes installed at $0.4 \mathrm{~m}$ height above the bottom. By means of gate valves, any of the 13 diffusers can be closed out of the aeration system. Two of the blowers are designed to operate, simultaneously, and one as stand by. The capacity of each blower is $460 \mathrm{~m}^{3} / \mathrm{hr}$ air flow rate with 0.45 bar. When two blowers feeding the chambers, the average air supply is 8.52 $\mathrm{L} / \mathrm{s}$ per meter length of each chamber. The standby one has been used for the pre-aeration system with aeration rate of $7.5 \mathrm{~m}^{3} \mathrm{air} / \mathrm{hr} . \mathrm{m}^{3}$ water.

\subsection{Materials and methods}

\subsubsection{Cases studied}

Six operational cases have been investigated through this study as described in the Table-1. Investigation of each case has been prolonged in operation for 7 days.

\subsubsection{Tests and measures}

(a) Sampling and testing

Sampling was carried out for one chamber (Chamber 1 in Figure1). For each of the six cases studied, three daily samples 


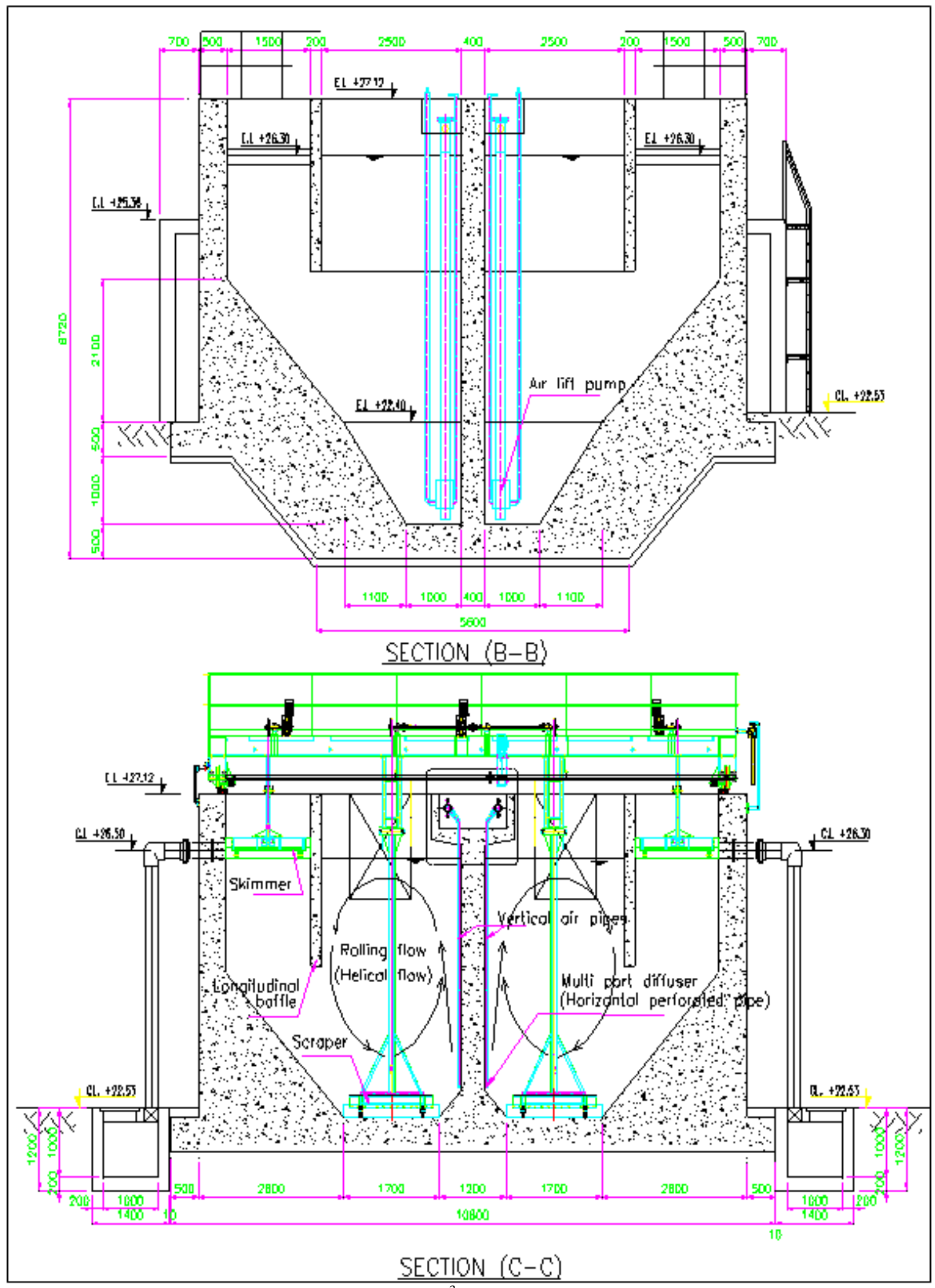

Figure.2: Cross sections of grit chamber at 50,000 m³/day capacity new municipal wastewater treatment plant of Kufa, [8]. 


\section{International Journal of Science and Research (IJSR) \\ ISSN (Online): 2319-7064}

Index Copernicus Value (2013): 6.14 | Impact Factor (2014): 5.611

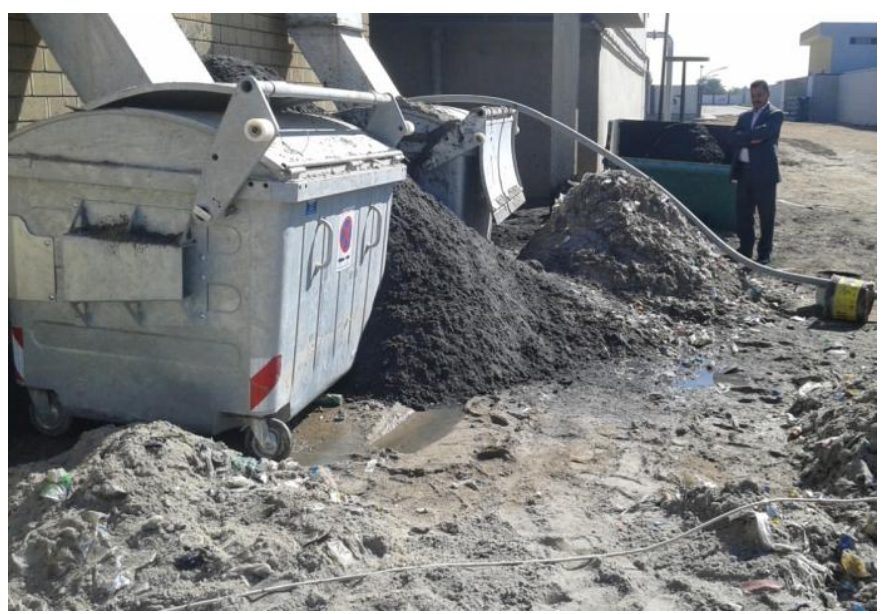

Photo 1: Heavy production of grits from aerated grit chamber of 50,000 $\mathrm{m}^{3} /$ day capacity new municipal wastewater treatment plant of Kufa, Iraq

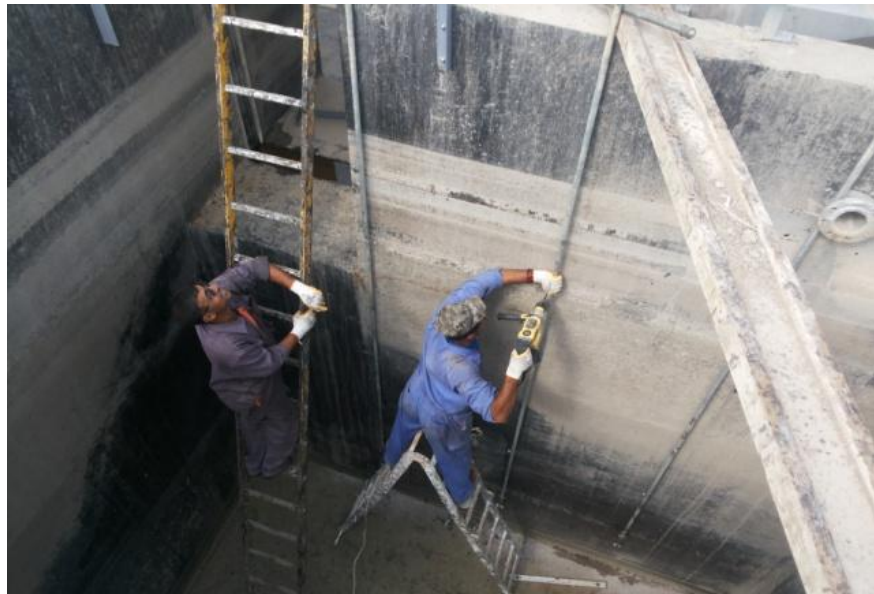

Photo 2: Pre-aeration made by means of vertical air pipes equipped with horizontal nozzles mounted on wall of reducing flow velocity basin at new municipal wastewater treatment plant of Kufa, Iraq

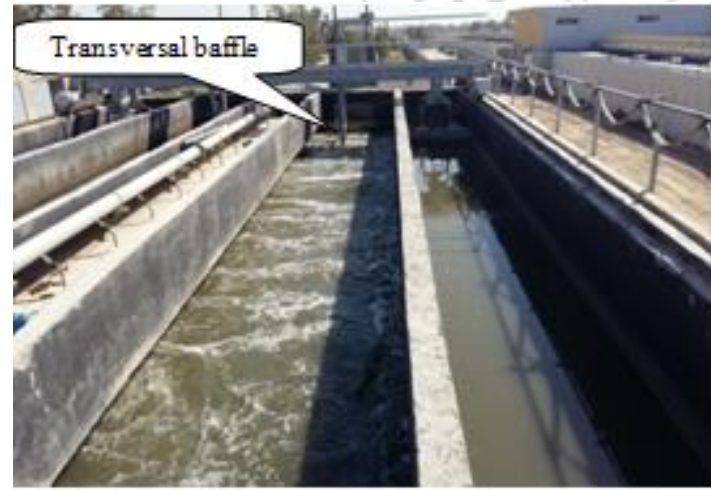

Photo 3: Transversal baffle situated ahead of end wall of the grit removal chambers at new municipal wastewater treatment plant of Kufa, Iraq.

for each of influent, effluent and settled grits were collected and tested. Sampling was carried out at 9:00am, 12:00pm and 2:00 pm in order to cover quality possible variation. Averages were considered for the results of the three daily samples. Influent and effluent samples were collected at water depths of $0.25 \mathrm{~m}$ from the inlet opening and outlet channel, whereas grit samples were collected from the inlet of the sand classifier.
Influent and effluent samples were tested for total suspended solids TSS, and oil and grease content O\&G, while grit samples were tested for total organic carbon TOC. All tests were carried out according to Standard Methods for the Examination of Water and Wastewater [16]. TSS test was according to, procedure 2540B. O\&G test was according to method 5520 C, Partition-Infrared Method using Infrared spectrophotometer, double-beam, recording. TOC test was carried out according to procedure 5310 [16].

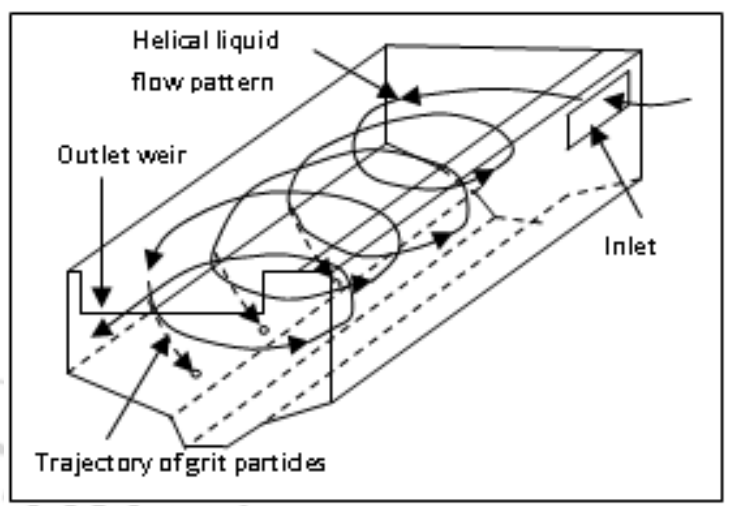

Figure 3: Sketch of helical flow pattern through an aerated grit removal chamber [1].

Table 1: Condition details of cases studied in one chamber.

\begin{tabular}{|c|c|c|c|c|c|}
\hline \multirow[b]{2}{*}{$\begin{array}{c}\text { Case } \\
\text { No. }\end{array}$} & \multirow{2}{*}{$\begin{array}{c}\text { Pre- } \\
\text { aeration } \\
\text { system }\end{array}$} & \multicolumn{2}{|c|}{$\begin{array}{c}\text { Transversal baffle } \\
\text { installation }\end{array}$} & \multirow{2}{*}{$\begin{array}{c}\text { No. of } \\
\text { diffusers } \\
\text { operating }\end{array}$} & \multirow[t]{2}{*}{ Notes } \\
\hline & & $\begin{array}{c}\text { Submerged } \\
\text { depth, } m\end{array}$ & \begin{tabular}{|c|} 
Submerged \\
depth/water \\
depth
\end{tabular} & & \\
\hline 1 & $\begin{array}{c}\text { Not } \\
\text { working }\end{array}$ & Not installed & Not installed & 13 & $\begin{array}{l}\text { This is the } \\
\text { normally } \\
\text { designed } \\
\text { case }\end{array}$ \\
\hline 2 & Working & Not installed & Not installed & 13 & \\
\hline 3 & Working & & 0.436 & 13 & \begin{tabular}{|c|} 
Same as \\
longitudinal \\
baffle depth
\end{tabular} \\
\hline 4 & Working & 0.85 & 0.218 & 13 & \\
\hline 5 & Working & 0.425 & 0.11 & 13 & \\
\hline 6 & Working & 0.85 & 0.218 & 12 & $\begin{array}{l}\text { Last diffuse } \\
\text { is closed }\end{array}$ \\
\hline
\end{tabular}

\section{(b) Field measurements}

Flow rate of the chambers was observed three times daily at the mean time of sampling mentioned in (a) above. Flow measurement was done by means of Parshal Flume installed downstream the chambers. The measured rates ware totals of the two chambers. To get a flow through one chamber the measures were divided by 2, given that the partial closure of the outlet and inlet gates of the chambers are the same (opened completely).

Longitudinal and transversal flow velocity distribution were carried out in one of the two chambers (chamber 1). The measurement has been done by means of a flow velocity meter specially developed for the field work. The meter was calibrated previously in a laboratory flume with a verity of flow rates and velocities. It can be situated in different orientations to measure horizontal flow velocity and vertical as well. Three transversal sections were adopted along the 


\section{International Journal of Science and Research (IJSR) \\ ISSN (Online): 2319-7064 \\ Index Copernicus Value (2013): 6.14 | Impact Factor (2014): 5.611}

chamber. First section was at $3.24 \mathrm{~m}$ behind the inlet wall, that is mean at $1.94 \mathrm{~m}$ from the boundaries of grit collecting pit and corresponds to the center of second diffuser, Figure 1. Second section was at $8.24 \mathrm{~m}$ from inlet wall, corresponding to the center of the $7^{\text {th }}$ diffuser. Third section was at $13.24 \mathrm{~m}$ from inlet wall, corresponding to the center of the $12^{\text {th }}$ diffuser. This arrangement of the three sections gives a spacing of $5 \mathrm{~m}$ between sections, with second section positioned at the center of the middle diffuser which is the middle of diffused section of the chamber. Each of the three transversal sections was subdivided into five successive bays of $0.5 \mathrm{~m}$ width each for the main channel of the chamber. At centerline of every bay, point (local) flow velocity was measured at water depths $0.25,0.75,1.25,1.75,2.25,2.75$ and $3.25 \mathrm{~m}$. These seven levels covers the expected helical flow domain. At each level, two local flow velocities were measured. One measure was parallel to main longitudinal flow direction denoted by (V). The other velocity measure was with a direction depended upon the level and bay sequence to measure local helical flow velocity, and denoted by $V_{\text {he }}$, Figure 4 . Each of $V$ and $V_{\text {he }}$, was divided by the main average flow velocity $\left(\mathrm{V}_{\mathrm{avg}}\right)$ of the chamber which theoretically calculated as flow through chamber divided by chamber cross sectional area. This is to get dimensionless relative velocity distribution along the chamber. The results of relative local velocity measures were used to draw contours of equal relative velocity. Such drawings facilitate following up flow velocity pattern through the chamber to evaluate effectiveness of helical flow.

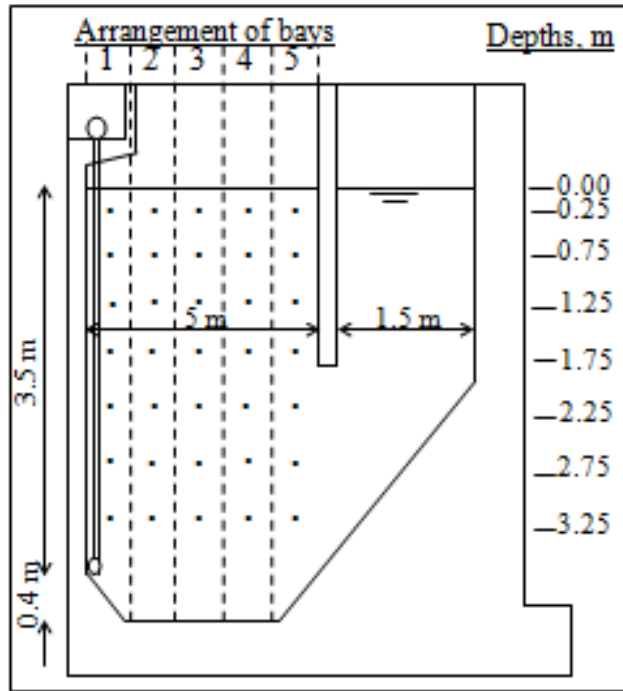

Figure 4: Distribution of local velocity measurement points through grit chamber cross-section

\section{Results and Discussion}

\subsection{Some of Influent Characteristics}

The incoming $700 \mathrm{~mm}$ dia. force main sewer pipe of the treatment plant is connected to a main pump station located just before the screens of plant preliminary treatment. The influent cannot come to the plant by gravity flow. Pumping is required to have the inflow entering the plant because the preliminary treatment (screens and grit removal chambers) are situated on $4.6 \mathrm{~m}$ above ground surface. Thus, the inflow is controlled by available flow and head capacities of the pump station. This expresses why the influent flow rate of the chamber studied had rather narrow range of $207-276$ L/s. Third column of Table 2 lists the inflows measured throughout the study. It can be observed that the flow was minimum during Thursdays, 207 - 257 L/s. This may belong to dominant activities of people served. As Friday and Saturday are the week end, most people of Najaf and Kufa cities keep visiting Kerbala city, $80 \mathrm{Km}$ north of Najaf, during Thursdays. This is beside that Thursdays are halftime working days for most governmental departments, schools, construction projects and industrial areas.

Figure 5 and Figure 6 illustrate relations between influent flow rate with each of influent TSS and O\&G, respectively. The two figures plotted form the resulted experimental data listed in columns $3^{\text {rd }}, 4^{\text {th }}$ and $6^{\text {th }}$ of Table 1 . The correlation is 0.88 and 0.59 for TSS and O\&G, respectively. The good correlation between inflow rate and TSS may reflect considerable discharge contribution of dewatering excavation sections of sewerage networks construction sites described in problem of study (section 2) above. Although O\&G, generally, increased with flow rate increase but, the relatively weak relation (of 0.59) may attributed to intermittent industrial effluents come from some food processing factories with limited capacities located in southern industrial area of Najaf city.

Coefficient of variation $\mathrm{Cv}$ is adopted in Table 3 to indicate the extent of variation of inflow and influent TSS and O\&G. Low values $(0.021$ - 0.093) of $\mathrm{Cv}$ for inflow rate certify stability of inflow rate. Low to moderate Cv values $(0.04-$ $0.194)$ for influent TSS and $(0.076-0.181)$ for influent O\&G permit good treatment control.

\subsection{Removal Efficiency}

Table 3 shows results of statistical handling for the resulted experimental data listed in Table 2. The mean of removal efficiency expressed in Table 3 is calculated for $(n=7)$ of test average results for each of the six cases as:-

Mean of Removal Efficiency =

$\left[\sum_{i=1}^{n}\right.$ (value in - value out)/value in $] / n$

Figure 7 demonstrates the mean of removal efficiency of TSS and O\&G achieved through each of the six cases studied. It is obvious that pre-aeration induced in case 2 caused the removal efficiency for both TSS and O\&G to increase from $14.9 \%$ and $7.33 \%$ into $21.35 \%$ and $17.14 \%$, respectively. This increase in TSS removal efficiency may be attributed to two reasons. First, the pre-aeration in the reducing velocity basin that prevented already settelable solids to settle out in the basin caused those solids to settle in the grit chamber, hence, increased solids removed in the chamber that increased its removal efficiency. Second, the pre-aeration enriched wastewater with more of air leading to decreasing water density which may enhanced separation of solids by means of gravity and/or centrifugal action of helical flow in the chamber. On the other hand, pre-aeration may increased the O\&G removal efficiency due to two 


\section{International Journal of Science and Research (IJSR) \\ ISSN (Online): 2319-7064 \\ Index Copernicus Value (2013): 6.14 | Impact Factor (2014): 5.611}

reasons. First, the pre-aeration caused fine bubbles to increase in the wastewater which increases free oil separation on top of wastewater in the skimming channel of the chamber. Second, extending aeration may lead to remove some of emulsified oils after reacting with Oxygen and, then, extracted with air bubbles [17].

Table 2: Wastewater quality results obtained for influent and effluent of grit chamber $1 *$

\begin{tabular}{|c|c|c|c|c|c|c|c|}
\hline \multirow[b]{2}{*}{ case } & \multirow[b]{2}{*}{ Date } & \multirow{2}{*}{$\begin{array}{c}\text { Flow } \\
\text { L/s }\end{array}$} & \multicolumn{2}{|c|}{ TSS } & \multicolumn{2}{|c|}{ O\&G } & \multirow{2}{*}{$\begin{array}{l}\text { Gri } \\
\text { TO } \\
\text { ppm }\end{array}$} \\
\hline & & & $\begin{array}{c}\text { Influent, } \\
\text { ppm }\end{array}$ & $\begin{array}{c}\text { Effluent } \\
\text { ppm }\end{array}$ & \begin{tabular}{|c|} 
Influent, \\
ppm
\end{tabular} & \begin{tabular}{|c|}
$\begin{array}{c}\text { Effluent, } \\
\text { ppm }\end{array}$ \\
\end{tabular} & \\
\hline \multirow{7}{*}{1} & Wed. 11-2-2015 & 266 & 770 & 652 & 236 & 219 & \\
\hline & \begin{tabular}{|l|l|l} 
Thu $12-2-2105$ \\
\end{tabular} & 257 & 682 & 610 & 169 & 162 & \\
\hline & Sat 14-2-2015 & 270 & 757 & 612 & 192 & 180 & \\
\hline & Sun 15-2-2015 & 275 & 781 & 634 & 180 & 173 & 11 \\
\hline & Mon 16-2-2015 & 271 & 722 & 658 & 214 & 198 & \\
\hline & \begin{tabular}{|l|} 
Tues. 17-2-2015 \\
\end{tabular} & 268 & 736 & 632 & 255 & 224 & \\
\hline & 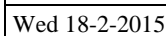 & 270 & 780 & 644 & 236 & 212 & 10 \\
\hline \multirow{7}{*}{2} & Sat 28-2-2015 & 274 & 771 & 586 & 172 & 142 & 19 \\
\hline & Sun 1-3-2015 & 257 & 634 & 517 & 195 & 167 & 11 \\
\hline & Mon 2-3-2015 & 264 & 693 & 528 & 225 & 177 & \\
\hline & Tues. 3-3-2015 & 267 & 721 & 606 & 246 & 204 & \\
\hline & Wed 4-3-2015 & 262 & 664 & 497 & 190 & 159 & \\
\hline & Thu 5-3-2015 & 221 & 524 & 418 & 147 & 122 & \\
\hline & Sat 7-3-2015 & 273 & 782 & 611 & 225 & 188 & \\
\hline \multirow{7}{*}{3} & Sat 14-3-2015 & 270 & 774 & 654 & 232 & 184 & \\
\hline & Sun 15-3-2015 & 268 & 758 & 661 & 219 & 178 & \\
\hline & Mon 16-3-2015 & 266 & 762 & 639 & 195 & 157 & 12 \\
\hline & \begin{tabular}{|l} 
Tues. $17-3-2015$ \\
\end{tabular} & 271 & 754 & 627 & 187 & 146 & 12 \\
\hline & Wed 18-3-2015 & 273 & 763 & 641 & 210 & 143 & 1 \\
\hline & \begin{tabular}{|l} 
Thu $19-3-2015$ \\
\end{tabular} & 207 & 586 & 518 & 186 & 139 & \\
\hline & Sat 21-3-2015 & 275 & 780 & 692 & 215 & 171 & \\
\hline \multirow{7}{*}{4} & Sun 22-3-2015 & 264 & 766 & 649 & 225 & 176 & \\
\hline & Mon 23-3-2015 & 267 & 778 & 671 & 190 & 158 & \\
\hline & Tues. 24-3-2015 & 270 & 761 & 647 & 205 & 173 & \\
\hline & Wed 25-3-2015 & 265 & 753 & 623 & 217 & 164 & \\
\hline & Thu 26-3-2015 & 241 & 577 & 498 & 184 & 157 & \\
\hline & Sat 28-3-2015 & 274 & 782 & 574 & 223 & 166 & \\
\hline & \begin{tabular}{|l|} 
Sun 29-3-2015 \\
\end{tabular} & 271 & 74 & 692 & 210 & 176 & \\
\hline \multirow{7}{*}{5} & Mon 30-3-2015 & 269 & 758 & 604 & 237 & 192 & 1 \\
\hline & Tues. 31-3-2015 & 273 & 732 & 598 & 229 & 195 & 1. \\
\hline & Wed 1-4-2015 & 270 & 687 & 586 & 186 & 168 & \\
\hline & Thu 2-4-2015 & 232 & 594 & 506 & 145 & 127 & \\
\hline & Sat 4-4-2015 & 276 & 780 & 633 & 210 & 182 & \\
\hline & Sun 5-4-2015 & 271 & 761 & 612 & 235 & 175 & \\
\hline & Mon 6-4-2015 & 272 & 74 & 39 & 251 & 184 & 1 \\
\hline \multirow{7}{*}{6} & Tues. 7-4-2015 & 269 & 762 & 597 & 243 & 192 & \\
\hline & Wed 8-4-2015 & 271 & 776 & 634 & 258 & 189 & 1 \\
\hline & Thu 9-4-2015 & 211 & 412 & 342 & 146 & 128 & \\
\hline & Sat 11-4-2015 & 271 & 632 & 485 & 194 & 143 & 1 \\
\hline & \begin{tabular}{|l|} 
Sun 12-4-2015 \\
\end{tabular} & 269 & 741 & 551 & 217 & 182 & \\
\hline & \begin{tabular}{|l|} 
Mon 13-4-2015 \\
\end{tabular} & 264 & 765 & 576 & 234 & 194 & 18 \\
\hline & Tues. 14-4-2015 & 270 & 780 & 623 & 255 & 207 & 15 \\
\hline
\end{tabular}

- Each value in the table represents an average result of three replicated samples and approximated to nearest integer

Back to Figure 7, the mean of removal efficiency of O\&G is increased from $17.14 \%$ to $22.64 \%$ with installing the transversal baffle of case 3 with $1.7 \mathrm{~m}$ submerged depth, while TSS removal decreased from $21.35 \%$ to $14.31 \%$. This may express the influence of the baffle to enhance retention of O\&G scum not to escape with the effluent in main channel of the chamber. At the mean time, the baffle decreased cross sectional area of the chamber main channel from about 8.75 $\mathrm{m}^{2}$ to $4.5 \mathrm{~m}^{2}$ causing effluent flow velocity to increase and thus minimize solids settling near the end of chamber main channel. This is explained on the basis of flow velocity pattern in the following section.

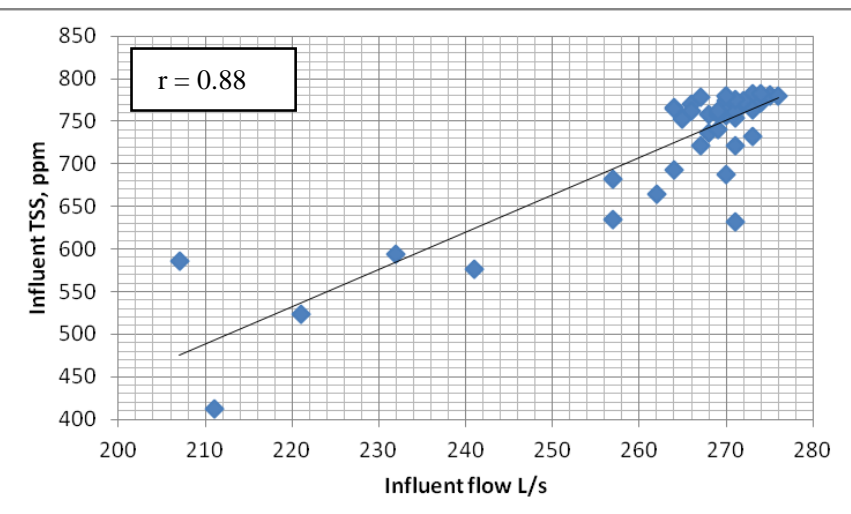

Figure 5: Influent TSS variation with inflow rate variation

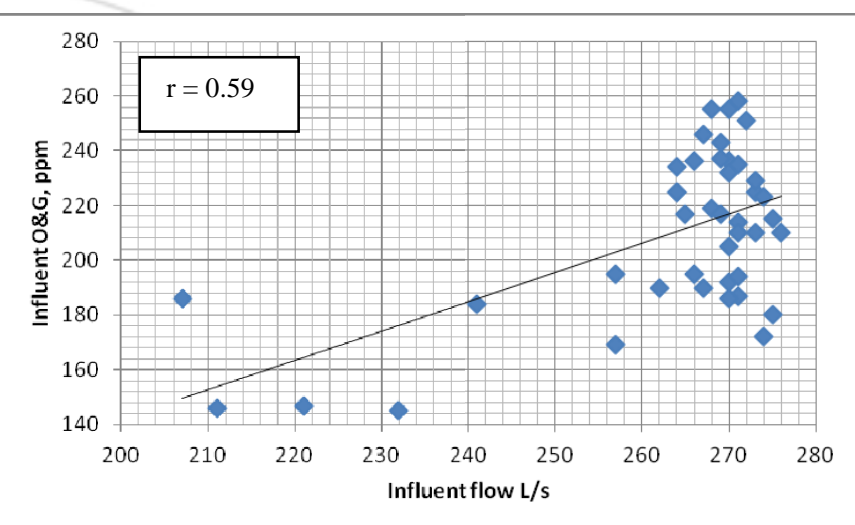

Figure 6: Influent O\&G variation with inflow rate variation

As the submerged depth of the transversal baffle decreased to $0.85 \mathrm{~m}$ in case 4 and $0.425 \mathrm{~m}$ in case 5 , the removal of TSS got better to $16.02 \%$ and $17.72 \%$, respectively. In contrast, the removal of O\&G decreased to $19.3 \%$ and $17.35 \%$ for the two cases 4 and 5, respectively. The same reason of the baffle of oil retention capacity and effluent flow velocity affected by net cross sectional area explained above may attribute this behavior. As the submerged depth is decreased, the net cross sectional area for the effluent increases leading to minimize longitudinal effluent flow velocity and enhance settling conditions which increase TSS removal. Baffle submerged depth decrease decreases O\&G retention capacity at the end of main channel with the presence of helical flow, leading to decreasing O\&G removal.

Case 6 adopted moderate submerged depth of $0.85 \mathrm{~m}$ to reach a balance between O\&G scum retention effect and moderate net cross sectional area of $6.63 \mathrm{~m} 2$ for the effluent. This is beside closing the last diffuser in order to minimize effluent turbulence and enhance settling conditions. This case achieved the best TSS removal of $21.53 \%$ with moderate $\mathrm{Cv}$ of 0.1505 . Good O\&G removal of $19.77 \%$ is achieved in this case, too, with moderate $\mathrm{Cv}$ of 0.2687 . Therefore, case 6 was the best one regarding dual removal of TSS and O\&G. 


\section{International Journal of Science and Research (IJSR) \\ ISSN (Online): 2319-7064 \\ Index Copernicus Value (2013): 6.14 | Impact Factor (2014): 5.611}

Figure 8 show the mean of TOC content in removed grits for $\quad$ the six cases listed in $10^{\text {th }}$ column of Table 3 . Variation of

Table 3: Removal efficiency of TSS and O\&G and TOC content of removed grits.

\begin{tabular}{|c|c|c|c|c|c|c|c|c|c|}
\hline \multirow[b]{2}{*}{ Case } & \multirow[b]{2}{*}{$\begin{array}{l}\text { Statistical } \\
\text { Parameter }\end{array}$} & \multirow{2}{*}{$\begin{array}{c}\text { Flow } \\
\text { L/s }\end{array}$} & \multicolumn{3}{|c|}{ TSS } & \multicolumn{3}{|c|}{ Oil and Grease } & \multirow[b]{2}{*}{$\begin{array}{l}\text { TOC } \\
\text { ppm }\end{array}$} \\
\hline & & & $\begin{array}{c}\text { Influent } \\
\text { ppm }\end{array}$ & $\begin{array}{l}\text { Effluent } \\
\text { ppm }\end{array}$ & \begin{tabular}{|l} 
Removal \\
Efficiency
\end{tabular} & $\begin{array}{l}\text { Influent } \\
\text { ppm }\end{array}$ & $\begin{array}{l}\text { Effluent } \\
\text { ppm }\end{array}$ & $\begin{array}{l}\text { Removal } \\
\text { Efficiency }\end{array}$ & \\
\hline \multirow{3}{*}{1} & Mean, $\dot{x}$ & 268.143 & 746.857 & 634.571 & 0.1490 & 211.714 & 195.429 & 0.0733 & \begin{tabular}{|l|l|}
87.429 \\
\end{tabular} \\
\hline & S & 5.640 & 36.159 & 18.537 & 0.0400 & 32.346 & 24.193 & 0.0302 & \begin{tabular}{|l|l|}
22.037 \\
\end{tabular} \\
\hline & $\mathrm{Cv}$ & 0.021 & 0.048 & 0.029 & 2685 & 0.153 & 0.124 & 0.4116 & 0.252 \\
\hline \multirow{3}{*}{2} & Mean, $\dot{x}$ & 259.714 & 684.143 & 537.571 & 0.2135 & 200.000 & 165.571 & 0.1714 & 149.286 \\
\hline & $\mathrm{S}$ & 18.090 & 88.622 & 69.375 & 0.0333 & 34.361 & 27.718 & 0.0211 & \begin{tabular}{|l|l|}
33.733 \\
\end{tabular} \\
\hline & $\mathrm{Cv}$ & 0.070 & 0.130 & 0.129 & 1560 & 0.172 & 0.167 & 0.1228 & 0.226 \\
\hline \multirow{3}{*}{3} & Mean, $\dot{x}$ & 261.429 & 739.571 & 633.143 & 0.1431 & 206.286 & 159.714 & 0.2264 & 101.143 \\
\hline & 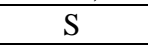 & 24.186 & 68.318 & 54.874 & 0.0234 & 17.433 & 18.053 & 0.0460 & 22.564 \\
\hline & $\mathrm{Cv}$ & 0.093 & 0.092 & 0.087 & 0.1634 & 0.085 & 0.113 & 0.2033 & 0.223 \\
\hline \multirow{3}{*}{4} & Mean, & 264.57 & 741.571 & 622.000 & 0.1602 & 207.714 & 167.143 & & 109.571 \\
\hline & 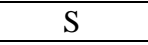 & 10.967 & 73.259 & 66.252 & 0.0508 & 15.850 & 8.050 & 0.0452 & 39.761 \\
\hline & $\mathrm{Cv}$ & 0.041 & 0.099 & 0.107 & 0.3173 & 0.076 & 0.048 & 0.2340 & 0.363 \\
\hline \multirow{3}{*}{5} & Mean, & 266.1 & 726.571 & 596.857 & & 213.286 & 174.714 & & 124.714 \\
\hline & $\mathrm{S}$ & 15.22 & 66.392 & 44.228 & 0.0222 & 36.791 & 22.991 & 0.0662 & 24.363 \\
\hline & $\mathrm{Cv}$ & 0.057 & 0.091 & 0.074 & 0.1250 & 0.172 & 0.132 & 0.3812 & 0.195 \\
\hline \multirow{3}{*}{6} & Mean, & 260.714 & 695.429 & 544.000 & 0.2153 & 221.000 & 176.429 & 0.1977 & 151.143 \\
\hline & $\mathrm{S}$ & 22.051 & 134.999 & 102.069 & 0.0324 & 39.892 & 29.262 & 0.0531 & 40.363 \\
\hline & $\mathrm{Cv}$ & 0.085 & 0.194 & 0.188 & 0.1505 & 0.181 & 0.166 & 0.2687 & 0.267 \\
\hline
\end{tabular}

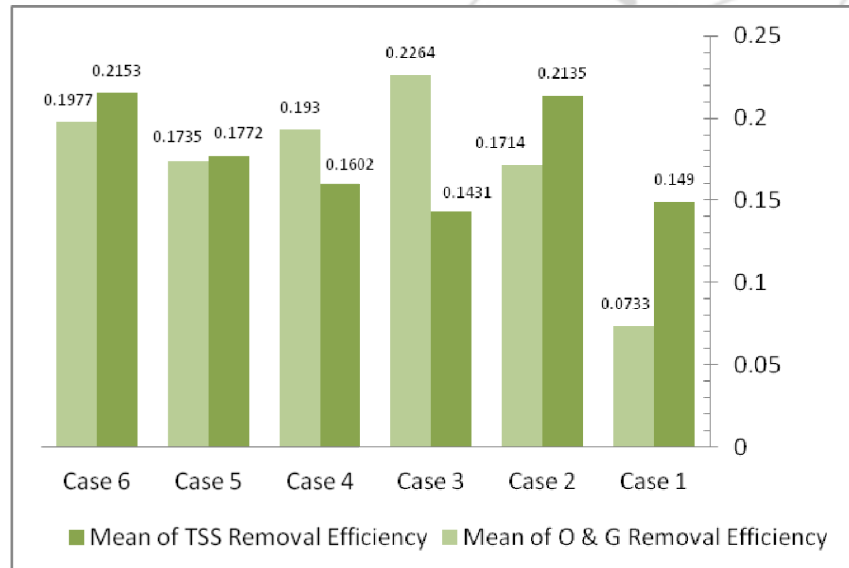

Figure 7: Mean removal efficiency of TSS and O\&G achieved in each of the six cases studied

TOC seems to follow TSS removal. Figure 9 illustrates the relation observed between the TOC and TSS/removed throughout the study (for all six cases studied). TSS removed values have been calculated as subtraction of effluent TSS $\left(4^{\text {th }}\right.$ column of Table 2$)$ from influent TSS ( $5^{\text {th }}$ column of same table). TOC values considered in the relation illustrated in Figure 9 is listed in column $8^{\text {th }}$ of Table 2. The relatively high correlation $(r=0.96)$ reflects quasi homogenous content of organic matter in the removed grits. The main function of grit removal chambers is to remove inorganic grits, mainly, as sand particle. To do so, detention time for the wastewater flow usually permitted in grit chambers is ranging between $2-5$ min at peak flow according to most design handbooks and manuals [1],[2]. Such detention time, usually, corresponds to $0.3 \mathrm{~m} / \mathrm{s}$ longitudinal flow velocity [18]. Considering the main flow will pass through the main channel of the five bays shown in Figure 4, the net active volume of one chamber is about 144 $\mathrm{m}^{3}$. This volume permits to have a detention time of $8.7 \mathrm{~min}$. at studied flow of $0.275 \mathrm{~m}^{3} / \mathrm{s}$. This time is rather double the usual desired. This may express settling out grits with relatively high organic content in present study. Relatively high organic content is detected by author through the odor emitted from the removed grits which have relatively dark color. On the other hand, increasing the detention time with continues aeration permits more $\mathrm{O} \& \mathrm{G}$ removal appurtinty [7], [17].

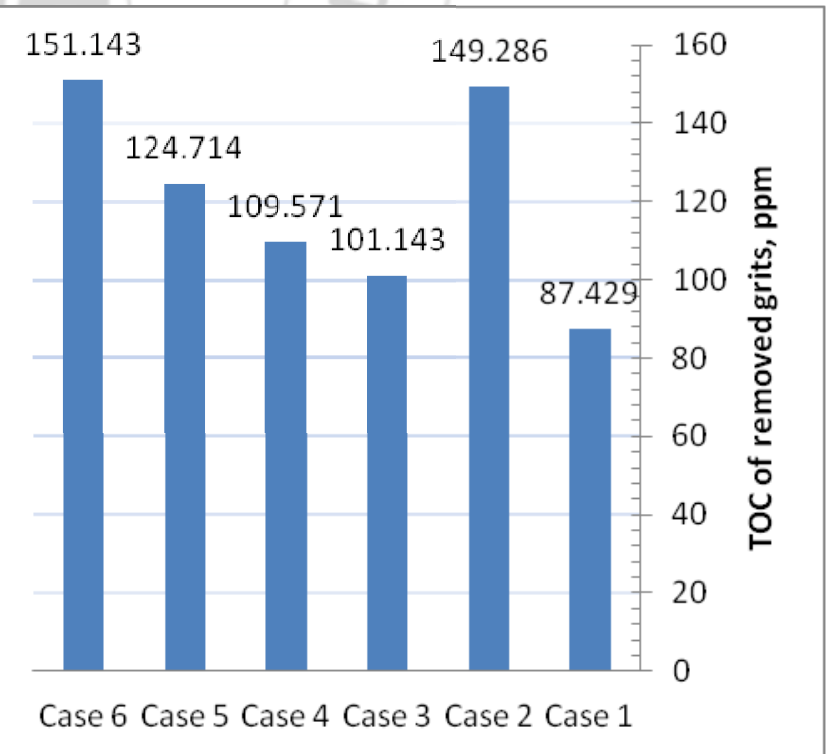

Figure 8: Mean values of TOC content in removed grits of the six cases 


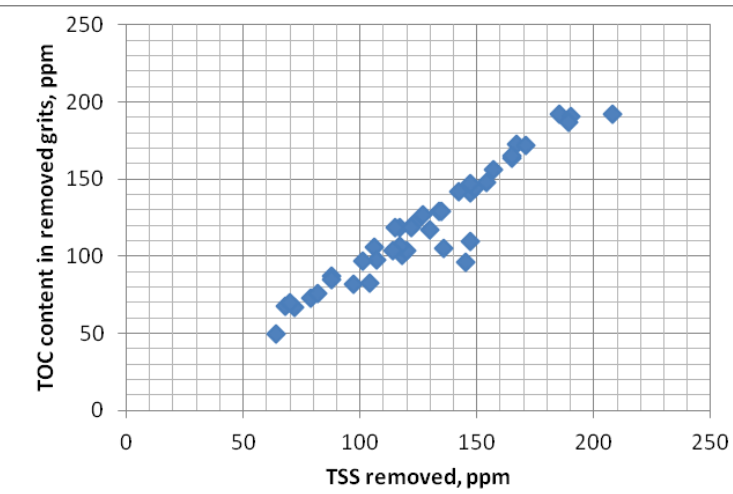

Figure 9: Relation observed between the TOC and TSS removed for all cases studied
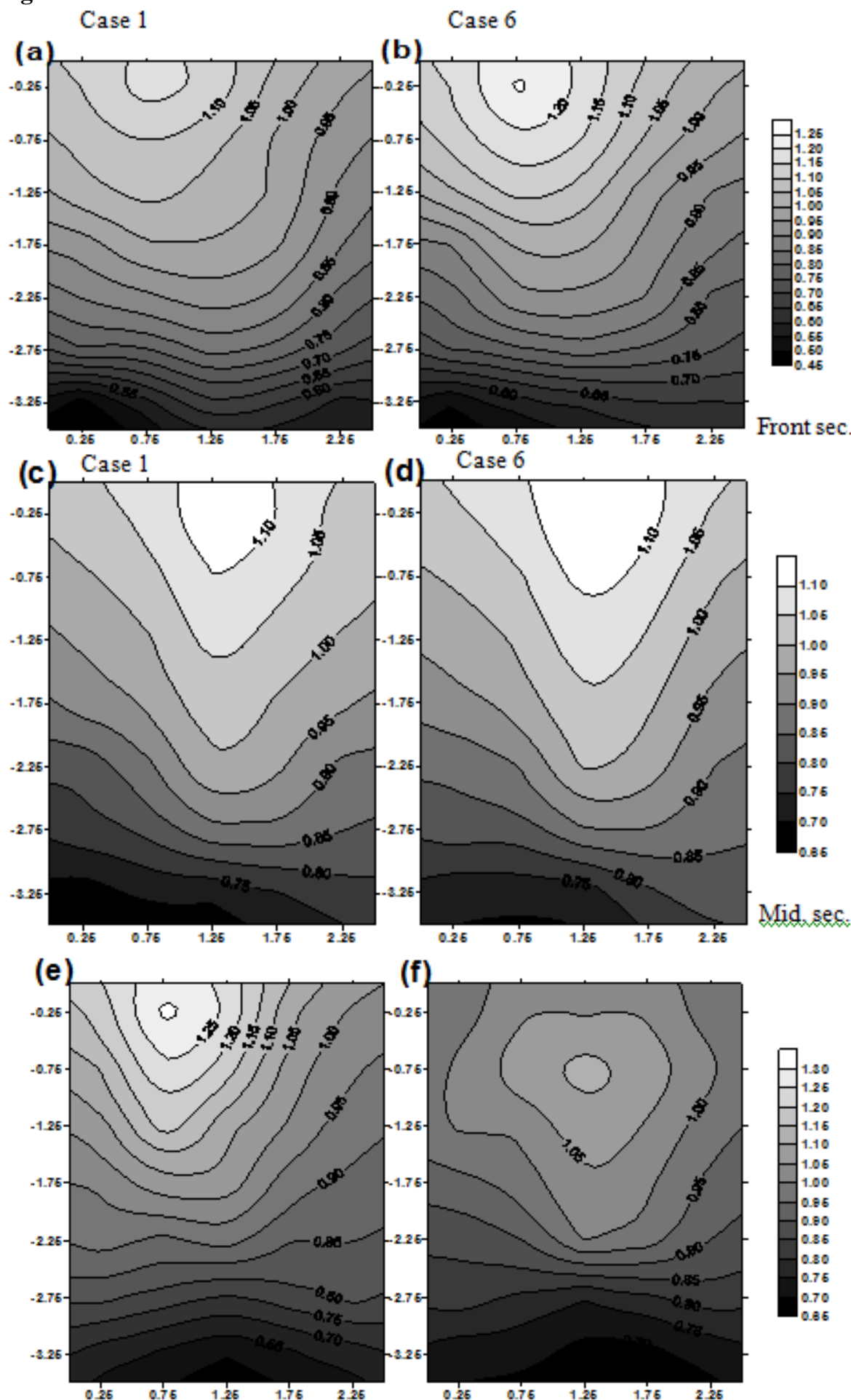

Figure 10: Relative longitudinal flow velocity (V/Vavg) distribution at three transversal sections for case 1 and case 6 .

Volume 5 Issue 3, March 2016 


\section{International Journal of Science and Research (IJSR) \\ ISSN (Online): 2319-7064}

Index Copernicus Value (2013): 6.14 | Impact Factor (2014): 5.611

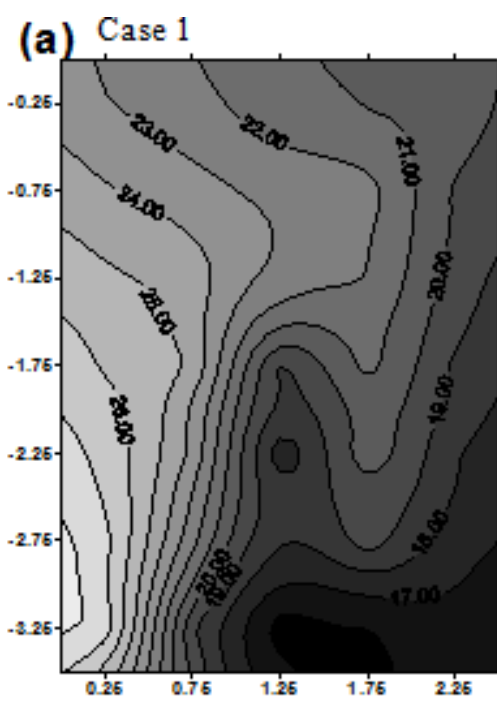

(b) Case 6

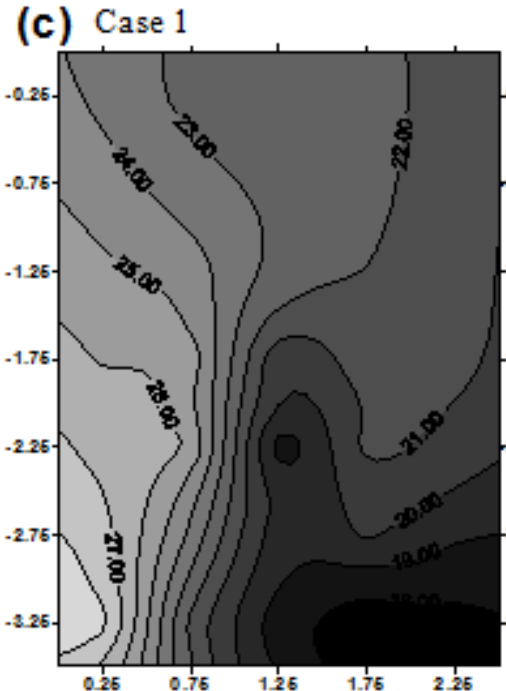

(d) Case 6
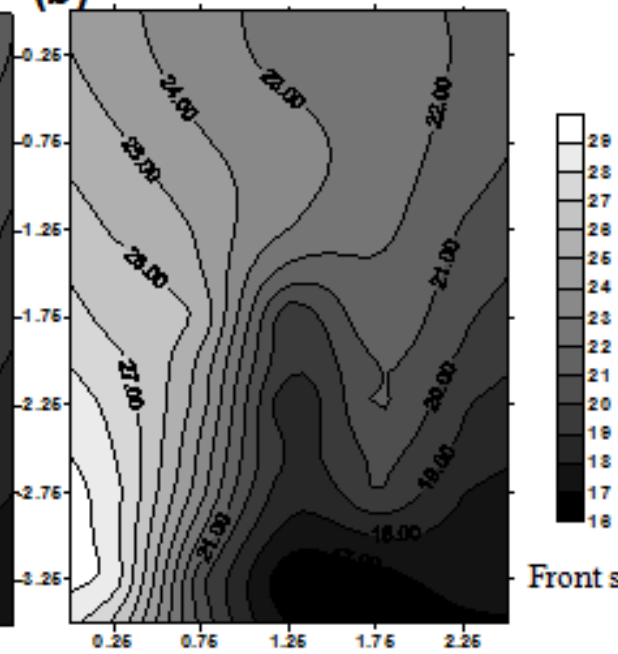

Front sec.

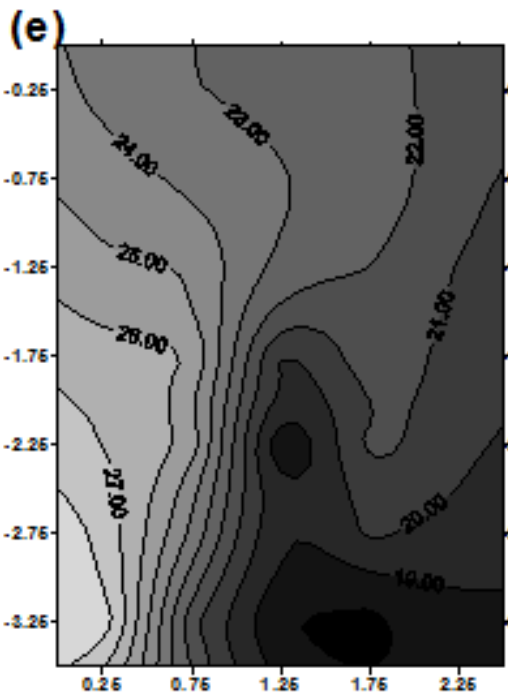

(f)
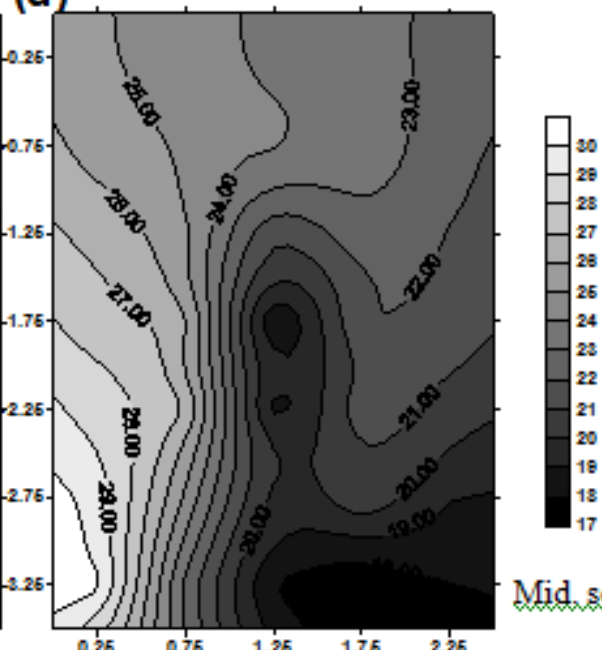

Mid sec.

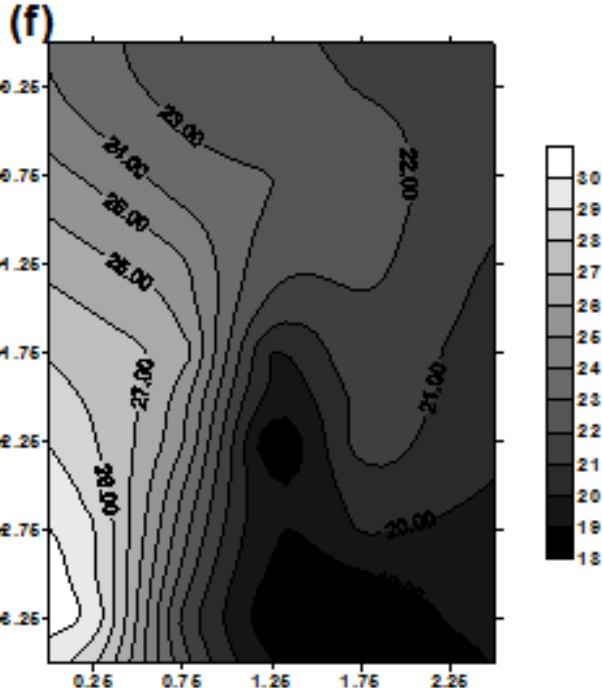

Figure 11: Relative transversal flow velocity (Vhe /Vavg) distribution at three transversal sections for case 1 and case 6.

\subsection{Flow velocity Patterns}

Figure 10 shows relative longitudinal flow velocity $\left(\mathrm{V} / \mathrm{V}_{\text {avg }}\right)$ distribution at the three transversal sections (front, mid and end) for case 1 and case 6, while Figure 11 shows the relative transversal (helical) flow velocity $\left(\mathrm{V}_{\mathrm{he}} / \mathrm{V}_{\mathrm{avg}}\right)$ distribution for the same sections and cases. From Figure 10, generally, main (longitudinal) flow velocity distribution has higher values near water top surface, and gradually lowered towards the bottom where reaching minimum values, while it has gradual intermediate values near side walls. This is the common flow velocity distribution in an open channel with channel width less than 10 water depth [19].

In Figure 10, When comparing the distributions of the front, mid and end sections of case 1 in drawings a, c and e, respectively, with corresponding distributions in drawings b, $\mathrm{d}$ and $\mathrm{f}$ of case 6 , it is obvious that installing the transversal 


\section{International Journal of Science and Research (IJSR) \\ ISSN (Online): 2319-7064 \\ Index Copernicus Value (2013): 6.14 | Impact Factor (2014): 5.611}

baffle caused the flow to has lower longitudinal velocity at the top surface in end section (compare drawings e and $\mathrm{f}$ ) with a factor of $25 \%$. Pre-aeration of case 6 may caused flow velocity distribution to has higher values near top surface with about $4-5 \%$, especially, at mid section (compare drawings a and $\mathrm{c}$ with $\mathrm{b}$ and $\mathrm{d}$, respectively). This may due to slight lowering water density and viscosity with presence of air bubbles in case 6, leading to less shear stress between water layers and more velocity gradient, especially, at top surface [19].

Relative transversal flow velocity distribution shown in Figure 11, generally, demonstrate clockwise water movement according to helical (rolling) flow induced by the side aeration along the chamber. Greater transversal velocities can be observed near the diffusers located at left bottom corner, while lower at the opposite right bottom corner. This is the desired transversal flow velocity distribution according to helical flow in aerated chambers. But, upward velocity is greater at the left bottom corner of case 6 (drawings $b$, $d$ and $f$ ) when compared with corresponding upward velocity in case 1 (drawings a, c and e). This may due to lowered water density and viscosity caused by pre-aeration in case 6 . The increase in the upward velocity is about $7 \%$ in mid and end sections, whereas it is only $3 \%$ at front section. This verity in the increase may be attributed to flow continuity and momentum effect. As water enters the chamber at front section it starts the helical motion due to the diffused air, but when reaching the mid section, helical motion is enhanced with continuous air diffusing along the chamber, and the flow become more sensitive to the increase in motion due to the change in original density and viscosity that reflected in continuity and momentum effect. This continuity has overcome the effect of closing the last diffuser in case 6 . No considerable effect of installing the transversal baffle in case 6 on helical flow velocity distribution as observed by comparing top surface of the drawings e and $\mathrm{f}$ in Figure 11.

\section{Conclusions}

The following conclusions can be drawn from the results of this study:-

1)The pre-aeration of $7.5 \mathrm{~m}^{3}$ air/ hr. $\mathrm{m}^{3}$ water increased TSS and O\&G removal efficiencies of the grit chamber with $43 \%$ and $134 \%$, respectively. TSS removal has increased from a mean value of $14.9 \%$ to $21.35 \%$, whereas the increase in O\&G removal was from a mean value of $7.33 \%$ to $17.14 \%$.

2)Installing the transversal baffle with a depth corresponds to $50 \%$ of water entire depth beside the pre-aeration of 7.5 $\mathrm{m}^{3}$ air/ hr. $\mathrm{m}^{3}$ water have together greater effect to increase O\&G removal efficiency with $209 \%$. The O\&G removal in such conditions has increased from $7.33 \%$ to $22.64 \%$.

3)The best dual removal efficiency for both TSS and O\&G was through installing the transversal baffle with submerged depth of $24 \%$ of entire water depth and the preaeration of $7.5 \mathrm{~m}^{3}$ air/ hr. $\mathrm{m}^{3}$ water. Such conditions increased TSS removal efficiency by $44.5 \%$ as from $14.9 \%$ to $21.53 \%$, and increased O\&G removal efficiency by $170 \%$ as from mean values of $7.33 \%$ to $19.77 \%$.
Installing the baffle in this condition neither adversely effected the helical flow velocity distribution pattern nor the longitudinal flow.

4)TOC tests for samples of removed grits showed direct relation between $\mathrm{OM}$ and removed TSS indicating relatively long detention time for the flow in the chamber causing considerable deposition of $\mathrm{OM}$ with the grits removed.

\section{References}

[1] Metcalf and Eddy Inc., Wastewater Engineering Treatment and Reuse, McGraw Hill, USA. 2003.

[2] Qasim, Syed R., Wastewater treatment plants planning , design, and operation, CRC Press LLC, USA. 1999.

[3] Steel, E. W. and McGhee, T.J., Water Supply and Sewerage, 6 Sub Edition, McGraw-Hill College. 1991.

[4] Vesilind P.A., Morgan S.M. and Heine L.G., Introduction to Environmental Engineering, $3^{\text {rd }}$ edition, Cengage Learning, USA, 2010

[5] Mihelcic J.R. and Zimmerman J. B., Environmental Engineering: Fundamentals, Sustainability, Design, John Wiley and Sons, Inc., USA, 2010.

[6] Nemerow N. L. and Agardy F. J., Strategies of Industrial and Hazardous Waste Management, Van Nostrand Reinhold ITP International Thomson Publishing Company, USA, 1998.

[7] Water Environment Federation, Industrial Wastewater Management, Treatment, and Disposal, Manual of Practice No.FD-3, $3^{\text {rd }}$ edition, WEF Press, Mc Graw Hill, USA, 2008.

[8] F \& B Investment Co., , "Designs and Drawing Sheets of Kufa New Wastewater Treatment Plant", unpublished drawings, 2012.

[9] Environmental Protection Agency, Wastewater Treatment Manuals; Preliminary Treatment, EPA, Ireland, 1995.

[10] Neighbors, J. B., and Cooper, T. W., Design and Operation Criteria for Aerated Grit Chambers, Water Sew. Works, 112, 12, 1965.

[11] Finger, R. E., and Parrick, J., "Optimization of Grit Removal at a Wastewater Treatment Plant", J. Water Pollut. Control Fed., Vol.52, No.8, pp: 2106-2116 ,1980.

[12] Albrecht, A. E., Aerated Grit Chamber Design and Operation, Water Sew. Works, 114, 9, 1967.

[13] Morales L. and Reinhart D., " Full-Scale Evaluation of Aerated Grit Chambers", J. Water Pollut. Control Fed., Vol. 56, No. 4, pp. 337-343, 1984.

[14] Al-Samawi A.A. and Hama A. R., " Evaluation of the Performance of the Aerated Grit Chambers Under No Maintenance Condition", Eng. \&Tech. Journal, Vol.32, Part (A), No.13, pp: 3257- 3271, 2014.

[15]Crites, R. and Tchobanoglous G., Small and Decentralized Wastewater Management Systems, McGraw-Hill, Companies. Boston, Massachusetts. 1998.

[16] Clescerl L. S., Greenberg A. E., and Eaton A. D. (Editors), , Standard Methods for the Examination of Water and Wastewater, 20th ed., American Public Health Association, American Water Works 
Association, Water Environment Federation, Washington, DC. 1999.

[17] Hung Y.T., Wang L. K., and Shammas N. K., Handbook of Environment and Waste Management: Volume 2: Land and Groundwater Pollution Control, World Scientific, 2013.

[18] Spellman F. R. and Whiting N. E., Environmental Engineer's Mathematics Handbook, CRC Press, USA, p437, 2005.

[19] Chow V. T., Open-Channel Hydraulics, McGraw Hill Book Company Inc., Japan, p.26,1959.

\section{Author Profile}

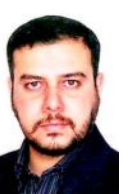

Hasan Al-Khateeb received the B.Sc. degree in Civil Engineering, M.Sc. degree and Ph.D in Civil/ Environmental Engineering from University of Mustansiriyah in 1994, 1997 and 2002, respectively. Since 2002, he conducted engineering consultations through designing several water and wastewater projects. He had been a vice dean for the Faculty of Engineering - University of Kufa for ten years (2004 - 2013). His research fields are Sanitary Engineering and Water Resources Engineering.

\begin{tabular}{|c|c|c|}
\hline Symbol & Definition & Dimensions \\
\hline TSS & Total suspended solids & $\mathrm{M} / \mathrm{L}^{3}$ \\
\hline O\&G & Oil and Grease & $\mathrm{M} / \mathrm{L}^{3}$ \\
\hline TOC & Total organic Carbon & ${\mathrm{M} / \mathrm{L}^{3}}^{3}$ \\
\hline OM & Organic Matter & $\mathrm{M} / \mathrm{L}^{3}$ \\
\hline $\mathrm{V}$ & Local longitudinal flow velocity. & $\mathrm{L} / \mathrm{T}$ \\
\hline $\mathrm{V}_{\mathrm{he}}$ & Local transversal flow velocity & $\mathrm{L} / \mathrm{T}$ \\
\hline $\mathrm{V}_{\mathrm{avg}}$ & Main (longitudinal) average flow & $\mathrm{L} / \mathrm{T}$ \\
\hline$\dot{\mathrm{X}}$ & velocity & --- \\
\hline $\mathrm{S}$ & Standard deviation & --- \\
\hline $\mathrm{Cv}$ & Coefficient of variation & --- \\
\hline $\mathrm{r}$ & Correlation coefficient & --- \\
\hline $\mathrm{n}$ & Number of tests done & --- \\
\hline
\end{tabular}

